\title{
Combining ability analysis in near homozygous lines of okra [Abelmoschus esculentus (L.) Moench] for yield and yield attributing parameters
}

\author{
Y. A. Lyngdoh ${ }^{1}$, R. Mulge ${ }^{2}$, A. Shadap ${ }^{3}$, Jogendra Singh ${ }^{1^{*}}$ and Seema Sangwan ${ }^{4}$ \\ ${ }^{1}$ Division of Vegetable Science, ICAR-IARI, New Delhi-110012, INDIA \\ ${ }^{2}$ Department of Vegetable Science, K.R.C. College of Horticulture, Arabhavi-591218 (Karnataka), INDIA \\ ${ }^{3}$ Bidhan Chandra Krishi Viswavidyalaya, Mohanpur -741252 (West Bengal), INDIA \\ ${ }^{4}$ Division of Microbiology, ICAR-IARI, New Delhi-110012, INDIA \\ *Corresponding author. E-mail: jogendra169@gmail.com
}

Received: May 9, 2016; Revised received: November 4, 2016; Accepted: January 30, 2017

\begin{abstract}
Line $\times$ tester analysis was carried out with the objective of identifying the good combiners and to decide the breeding strategies for developing potential and productive genotypes or cultivars. Parents and hybrids differed significantly for GCA and SCA effects for all the characters respectively. Specific combining ability (SCA) variance was higher than the general combining ability (GCA) variance which shows the predominance of non-additive gene action for the improvement of all the characters studied. The parents and crosses having highest and significant GCA and SCA effects viz., KO-18 (13.69), KO-6 (9.54) and KO-2 × Parbhani Kranti (19.28) for plant height; KO-12 (0.34), KO-14 (0.19) and KO-5 × V5 (0.60) for number of branches per plant; KO-14 (-0.66) and KO-15 $\times$ Arka Anamika(-1.66) for days to first flowering; KO-1(1.10), Arka Anamika (0.46) and KO-9 $\times$ VRO-5 (3.28) for fruit length; KO-7 (7.91), VRO-5(1.68) and KO-18 x VRO-6 (8.64) for average fruit weight; KO-2 (1.18) and KO-17 × Arka Anamika (2.80) for number of fruits per plant; KO-9(0.05), VRO-6 (0.01) and KO-11 $\times$ VRO-6 (0.10) for total yield per plant were identified as good general and specific combiners. The results establish the worth of heterosis breeding for effective usage of non-additive genetic variance in okra.
\end{abstract}

Keywords: Combining ability, Okra, Line $\times$ tester, Variance

\section{INTRODUCTION}

Okra [Abelmoschus esculentus (L.) Moench] commonly recognized as bhendi or lady's finger is a fast growing annual crop which has acquired a spectacular status among vegetables in India. Being a native of Tropical Africa it is grown for its tender fruits in tropics, subtropics and warmer seasons of the temperate areas in the world. This crop is gaining its importance as it has multiple uses where it can be used as a vegetable, eaten boiled, sliced and then sundried or canned and dehydrated for off season use.

Combining ability is the capacity of an individual to transmit superior performance to its offspring determining the relative magnitude of additive and non-additive gene effects (Griffing, 1956) for developing potential and productive genotypes or cultivars. General combining ability measures average performance of a parent in hybrid combination and specific combining ability is the performance of a hybrid that is expected on the basis of average performance of parents involved. The main problem for cultivation of okra in India is lack of location specific high yielding varieties. Initially selection of okra was made from locally adapted population and exploitation of hybrid vigour and selection of parents on the basis of combining ability has opened a new line of approach in crop improvement. Therefore, for a systematic breeding programme, it is essential to identify the parents, as well as crosses which could be exploited in order to bring about further genetic improvement in economic characters. The line $\times$ tester analysis is one of the techniques where a large number of genotypes could be tested for their combining ability. GCA and SCA effects estimates have a direct bearing on the breeding methods that could be adopted in okra improvement programme (Singh et al., 2009; Wammanda et al., 2010; Reddy et al., 2011; Kumar and Reddy, 2016). Earlier reports of researchers (Kumar et al., 2006; Singh et al., 2009; Wammanda et al., 2010; Reddy et al., 2011; Singh and Goswami, 2015; Bhatt et al., 2015; Kumar and Reddy, 2016) indicated that both additive and non-additive genetic systems control yield and yield contributing traits in okra. However, higher magnitude of non-additive genetic effects was the major part of genetic variation for yield and yield contributing traits in okra (Kumar et al., 2006; Wammanda et al., 2010; Reddy et al., 2011; Singh and Goswami, 2015; Bhatt et.al., 2015; Kumar and Reddy, 2016). However, genetic investigation of transmission of various important characters has remained far from fully explored in okra. Hence an attempt has been made to 
estimate the GCA and SCA variances in the okra population; to evaluate the breeding potential per se in specific combinations (SCA) and their overall performance in crosses (GCA) respectively, to identify the best combiners among the existing germplasm as well as to study the gene action of different quantitative characters in line $\times$ tester analysis for formulation of a sound and effectual breeding programme in okra.

\section{MATERIALS AND METHODS}

Choice of parental material: The parental materials available at the Department of Vegetable Science, Kittur Rani Channanna College of Horticulture, Arabhavi were utilized for the study. The lines were near homozygous and were selected based on their per se performance for yield and quality attributes and relatively free from yellow vein mosaic virus incidence.

Generating breeding material: 72 hybrids were derived by crossing 18 lines and 4 testers (Parbhani Kranti, Arka Anamika, VRO-5 and VRO-6) in the first season.

Experimental design and crop management: All the 72 hybrids along with their parents, testers and a commercial hybrid (MHY-10) were evaluated in a randomized block design with three replications during 20102011 at the Department of Vegetable Science, K.R.C. College of Horticulture, Arabhavi, Gokak Taluk, Belgavi district, Karnataka, India. Each treatment or a genotype in each replication was represented by one row each accommodating 20 plants at a row to row spacing of $60 \mathrm{~cm}$ and $30 \mathrm{~cm}$ from plant to plant. The experimental farm is situated at Northern Dry Zone of Karnataka at $16^{\circ} 15^{\prime} \mathrm{N}$ latitude, $74^{\circ} 45^{\prime} \mathrm{E}$ longitude and at an altitude of 612.03 meters above the mean sea level. Arabhavi, which comes under the Zone-3 of Region-2 among the agro-climatic zones of Karnataka, has benefits of both the South-west and north-east monsoons. The average rainfall of this area is about $522 \mathrm{~mm}$, distributed over a period of five to six months (June to November) with peaks during October. The command area receives water from Ghataprabha Left Bank Canal from mid-July to mid-March.

Recording of biometric data: Five plants were randomly selected for each genotype from each replication and evaluated for the quantitative characters such as plant height $(\mathrm{cm})$, intermodal length $(\mathrm{cm})$, number of branches per plant, number of nodes on main stem, days to first flowering, number of nodes at first flowering, number of nodes at first fruiting, fruit length $(\mathrm{cm})$, fruit diameter $(\mathrm{mm})$, average fruit weight $(\mathrm{g})$, number of fruits per plant, total yield per plant $(\mathrm{g})$, number of ridges per fruit, number of locules per fruit and number of seeds per fruit.

Statistical analysis: The mean values of the data recorded were analyzed statistically adopting the method suggested by Kempthorne (1957).

\section{RESULTS AND DISCUSSION}

The analysis of combining ability is one of the potential tools used for identification of prospective parents to develop commercial $F_{1}$ hybrids (Griffing, 1956). General and specific combining ability effects and variances obtained from a set of $\mathrm{F}_{1}$ 's would enable a breeder to select desirable parents and crosses for each of the quantitative components. General combining ability effects of parents and SCA effects of crosses were highly significant for the characters studied. The variance due to general combining ability (GCA), specific combining ability (SCA) and GCA to SCA ratio for various characters are presented in Table 1. SCA variances estimation was high for all the characters studied, which indicated the importance of nonadditive gene action for the improvement of these characters. The estimates of GCA/SCA ratio (variance ratio) indicated that a relatively higher proportion of SCA was responsible for the expression of all the traits. This result is expected as okra is a cross pollinated crop thus exhibiting predominance of dominance genetic variance in comparison to additive component. The results are in conformity with the findings of $\mathrm{Ku}$ mar et al. (2006), Singh and Syamal (2006), Weerasekara (2006), Srivastava et al. (2008), Singh et al. (2009), Solankey and Singh (2010), Singh and Goswami (2015), Bhatt et al. (2015) and Kumar and Reddy (2016) in okra for days to first flowering, plant height, primary branches per plant, fruit length, fruit girth, fruit weight, fruits per plant and fruit yield per plant. A perusal of the result revealed that in most of the cases per se performance of parents bear direct reflection of their respective GCA effects, i.e. parents showing highest GCA effects for a character, were also observed to be good performer with respect to that particular character.

The statistical data of general combining ability effects (Table 2) of the lines and testers indicates that none of the parental lines were good combiners for all the traits. The lines, KO-18 and KO- 6 were the best general combiner for plant height whereas KO-12 and VRO-6 were the best general combiners for number of branches per plant among lines and testers. For days to first flowering, KO-14 among lines showed as the best general combiner whereas none of the tester expressed significant GCA effect. Among the testers, VRO-5 and line $\mathrm{KO}-15$ were best general combiner for flowering at early node, whereas, KO-6 among lines and Parbhani Kranti among testers came out as best general combiners for shorter internodal length. The lines, KO-1, KO-18 and tester, Arka Anamika were most effective general combiners for fruit length. The best general combiner line and tester for fruit diameter were KO-7 and Arka Anamika, respectively. For average fruit weight, the lines, KO-6 and KO-16 and the tester, VRO-5 were the best general combiners. For number 
Y.A. Lyngdoh et al. / J. Appl. \& Nat. Sci. 9 (1): 324 - 331 (2017)

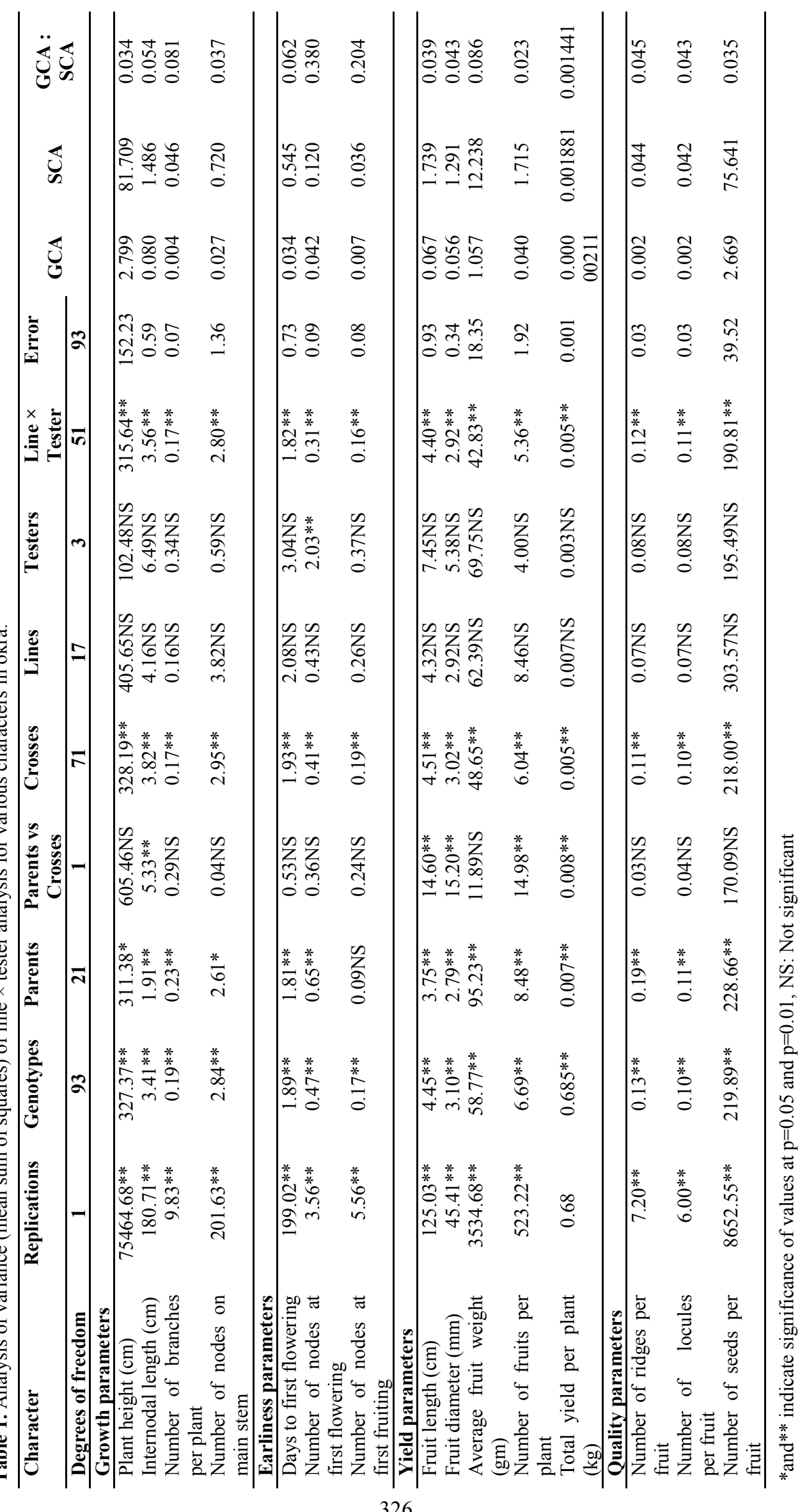


Y. A. Lyngdoh et al. / J. Appl. \& Nat. Sci. 9 (1): 324 - 331 (2017)

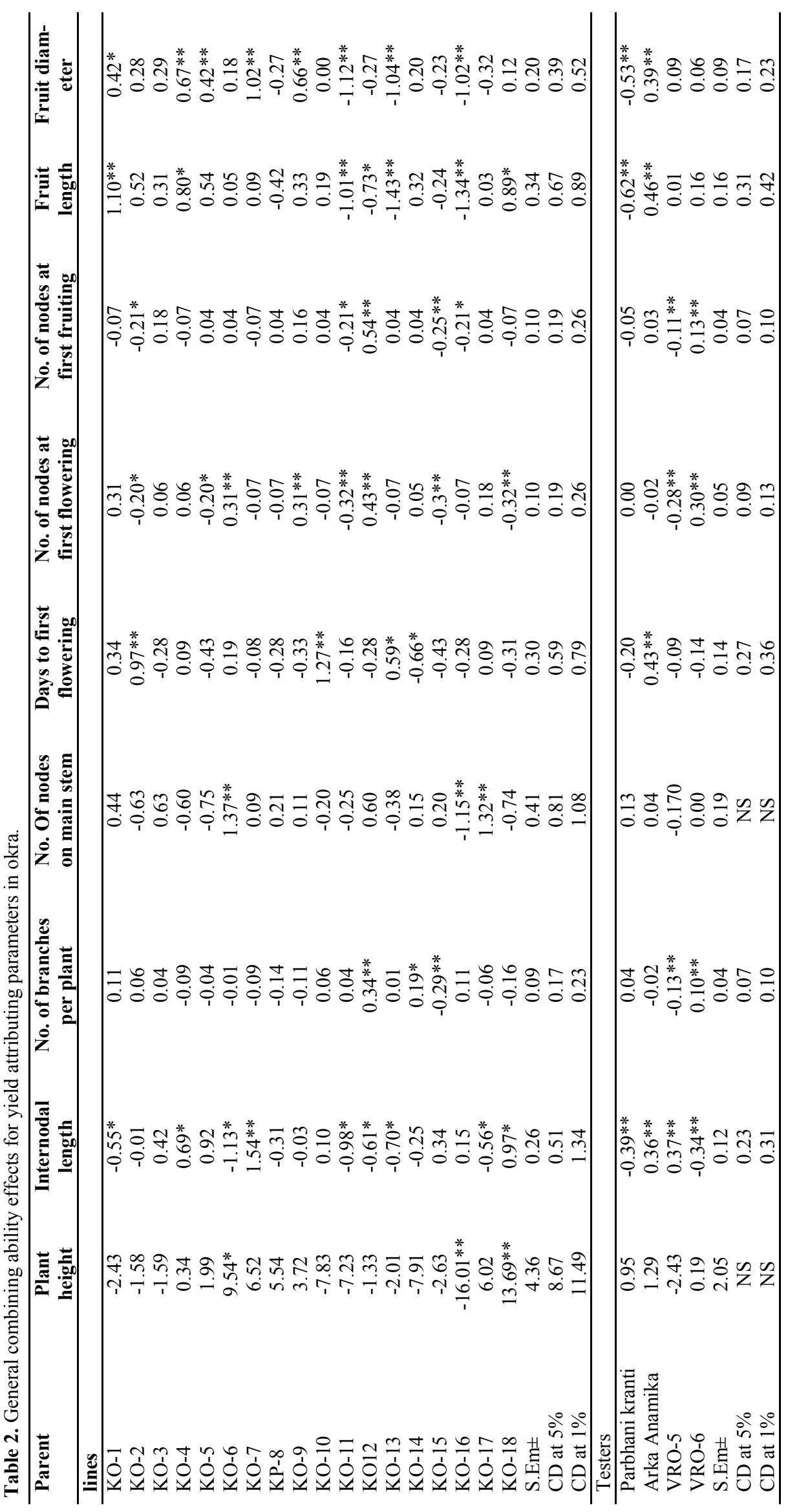


Y. A. Lyngdoh et al. / J. Appl. \& Nat. Sci. 9 (1): 324 - 331 (2017)

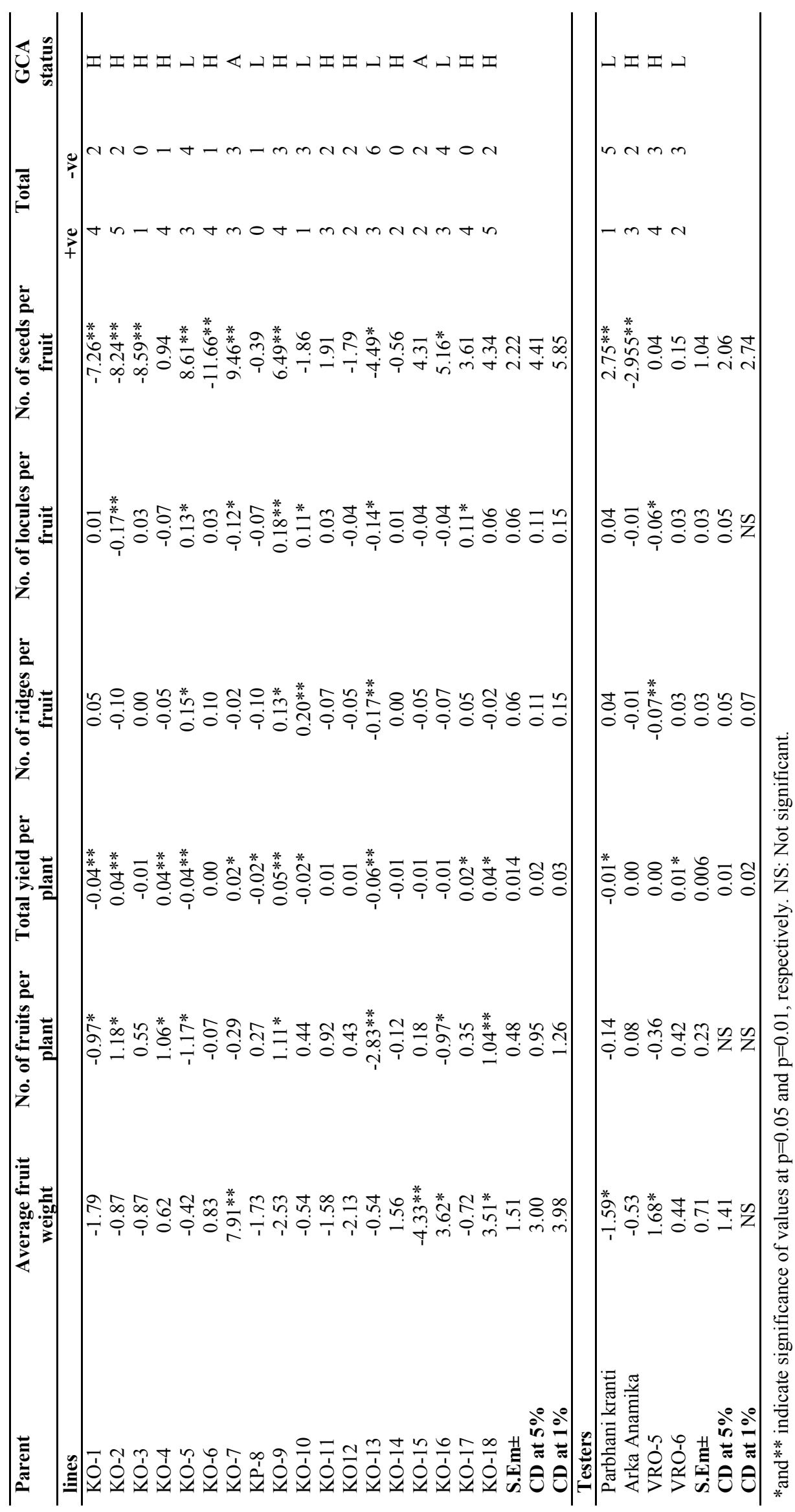


Y.A. Lyngdoh et al. / J. Appl. \& Nat. Sci. 9 (1): 324 - 331 (2017)

Table 3. Top three desirable hybrids with respect to SCA effects for various characters in okra.

\begin{tabular}{|c|c|c|c|c|c|}
\hline \multirow{2}{*}{ Character } & \multirow{2}{*}{ Crosses } & \multirow{2}{*}{ SCA } & \multirow{2}{*}{ Mean } & \multicolumn{2}{|c|}{ GCA Status } \\
\hline & & & & Female & Male \\
\hline \multirow[t]{3}{*}{ Plant height } & KO-2 $\times$ Parbhani kranti & 19.28 & 98.70 & High & Low \\
\hline & KO-12 × VRO-6 & 18.78 & 97.70 & High & Low \\
\hline & KO-7 $\times$ Parbhani Kranti & 17.88 & 105.40 & Average & Low \\
\hline \multirow[t]{3}{*}{ Internodal length } & $\mathrm{KO}-5 \times \mathrm{VRO}-5$ & -2.87 & 5.05 & Low & High \\
\hline & KO-10 $\times$ Arka Anamika & -2.19 & 4.90 & Low & High \\
\hline & KO-13 $\times$ VRO-5 & -1.99 & 4.30 & Low & High \\
\hline \multirow[t]{3}{*}{ No. of branches per plant } & KO-5 $\times$ VRO-5 & 0.60 & 1.90 & Low & High \\
\hline & KO-12 × VRO-5 & 0.43 & 2.10 & High & High \\
\hline & KO-15 × VRO- 6 & 0.42 & 1.70 & Average & Low \\
\hline \multirow[t]{3}{*}{ No. of nodes on main stem } & $\mathrm{KO}-4 \times \mathrm{VRO}-6$ & 2.18 & 36.50 & High & Low \\
\hline & KO-6 $\times$ Parbhani Kranti & 1.97 & 37.90 & High & Low \\
\hline & KO-1 × Arka Anamika & 1.69 & 36.50 & High & High \\
\hline \multirow[t]{3}{*}{ Days to first flowering } & KO-15 × Arka Anamika & -1.66 & 13.20 & Average & High \\
\hline & KO-10 $\times$ Parbhani Kranti & -1.32 & 15.10 & Low & Low \\
\hline & KO-16 × VRO-5 & -1.28 & 13.80 & Low & High \\
\hline \multirow[t]{3}{*}{ No. of nodes at first flowering } & KO- $2 \times$ VRO- 6 & -0.81 & 2.50 & High & Low \\
\hline & KO- $6 \times$ VRO- 6 & -0.80 & 3.02 & High & Low \\
\hline & KO-16 × Parbhani Kranti & -0.64 & 2.50 & Low & Low \\
\hline \multirow[t]{3}{*}{ No. of nodes at first fruiting } & KO- $2 \times$ VRO- 6 & -0.55 & 2.50 & High & Low \\
\hline & KO-12 × VRO-5 & -0.50 & 3.07 & High & High \\
\hline & KO-9 × VRO-6 & -0.43 & 3.00 & High & Low \\
\hline \multirow[t]{3}{*}{ Fruit length } & $\mathrm{KO}-9 \times \mathrm{VRO}-5$ & 3.28 & 20.86 & High & High \\
\hline & KO-3 $\times$ Parbhani Kranti & 2.30 & 19.23 & High & Low \\
\hline & KO-16 × Parbhani Kranti & 2.22 & 17.50 & Low & Low \\
\hline \multirow[t]{3}{*}{ Fruit Diameter } & KO-9 $\times$ VRO-5 & 2.25 & 20.07 & High & High \\
\hline & KO-6 $\times$ Parbhani Kranti & 2.13 & 18.85 & High & Low \\
\hline & KO-3 $\times$ Parbhani Kranti & 1.94 & 18.77 & High & Low \\
\hline \multirow[t]{3}{*}{ Average Fruit Weight } & KO-18 × VRO-6 & 8.64 & 44.17 & High & Low \\
\hline & KO-14 × Arka Anamika & 7.91 & 40.52 & High & High \\
\hline & KO-2 $\times$ Parbhani Kranti & 7.43 & 36.55 & High & Low \\
\hline \multirow[t]{3}{*}{ No. of fruits per plant } & KO-17 $\times$ Arka Anamika & 2.80 & 14.74 & High & High \\
\hline & KO-9 $\times$ VRO-5 & 2.59 & 14.86 & High & High \\
\hline & KO-7 $\times$ Parbhani Kranti & 2.35 & 13.44 & Average & Low \\
\hline \multirow[t]{3}{*}{ Total yield per plant } & KO-11 × VRO-6 & 0.10 & 0.407 & High & Low \\
\hline & KO-2 $\times$ Parbhani Kranti & 0.09 & 0.409 & High & Low \\
\hline & KO-14 × Arka Anamika & 0.09 & 0.359 & High & High \\
\hline \multirow[t]{3}{*}{ No. of ridges per fruit } & KO-18 $\times$ VRO- 6 & -0.43 & 4.90 & High & Low \\
\hline & KO-17 × VRO-5 & -0.41 & 4.90 & High & High \\
\hline & KO-2 $\times$ Parbhani Kranti & -0.36 & 4.90 & High & Low \\
\hline \multirow[t]{3}{*}{ No. of locules per fruit } & KO-18 $\times$ Parbhani Kranti & 0.83 & 6.20 & High & High \\
\hline & KO-2 $\times$ VRO-5 & 0.36 & 5.40 & High & High \\
\hline & KO-5 $\times$ Parbhani Kranti & 0.36 & 5.80 & Low & Low \\
\hline \multirow[t]{3}{*}{ No. of seed per fruit } & KO-9 $\times$ Arka Anamika & 19 & 66.90 & High & High \\
\hline & KO-8 $\times$ Arka Anamika & 18.77 & 59.80 & Low & High \\
\hline & KO-3 $\times$ Parbhnai Kranti & 16.97 & 55.50 & High & Low \\
\hline
\end{tabular}

of fruits per plant, KO-2 among lines presented as best general combiner. On the basis of fruit yield KO-9 and KO-18 among lines and VRO-6 among testers were recorded to be best general combiners.

Based on the total scoring values it was observed that among the female parents, line KO-17 had higher GCA score and is a good combiner for intermodal length, number of nodes on main stem, fruit yield per plant and number of locules per fruit. It was followed by line KO-18 which is good combiner for plant height, fruit length, average fruit weight, number of fruits per plant and total yield per plant. Among the testers, VRO-5 and Arka Anamika had high GCA score. Therefore, on the basis of per se performance and general combining ability effects of the lines/ testers, the lines viz., KO-17, KO-18, KO-2, KO-4 and KO-6 and testers viz., Arka Anamika and VRO-5 appeared to be desirable parents which could be used in hybridization programme.

From the data it is quite evident that none of the hybrids were having higher SCA effect for all the characters. Therefore, top three crosses exhibiting high SCA effects were selected for each character and GCA status of respective parents was presented as either low or high (Table 3). The results obtained from the present investigation indicated that the majority of the 
crosses exhibited high SCA effects as a result of either high $\times$ low, high $\times$ high or low $\times$ high GCA parents, indicating a genetic interaction of the additive $\times$ dominance, additive $\times$ additive or dominance $\times$ additive type.

Earliness is an important trait in okra as it helps in realizing the potential economic yield in as less time as possible to catch early market. Days to first flowering, number of nodes at first flowering and fruiting are indications of earliness. The crosses showing better performance for the characters determining earliness involved the parents with high $\times$ low, average $\times$ high GCA parents, indicating both additive and nonadditive gene action.

For fruit length and fruit width, KO-9 $\times$ VRO-5 had the highest specific combining ability effect. Further, the cross KO-18 $\times$ VRO- 6 had the highest positive specific combining ability along with superior performance for average fruit weight. The cross, KO-16 $\times$ Arka Anamika was the most efficient with high SCA effect for number of fruits per plant. In these characters studied majority of the crosses exhibited high SCA effects as a result of either high $\times$ high, low $\times$ low, high $\times$ low general combining ability effects indicating the presence of both additive and non-additive gene action. Similar findings were also reported by Singh and Syamal (2006) for plant height, number of nodes per plant, number of fruits per plant, average fruit weight, total yield per plant and number of seeds per fruit; Weerasekara (2006) for plant height, intermodal length, number of branches per plant, number of nodes at first flowering, fruit length, fruit diameter, average fruit weight, number of fruit per plant, number of ridges per fruit and number of seeds per fruit; Manivannan et al. (2007) for plant height, fruit length, number of ridges per fruit and number of seeds per fruit; Solankey and Singh (2010) for plant height, intermodal length, number of branches per plant, number of nodes on main stem, days to first flowering, fruit length, fruit diameter, average fruit weight, number of fruits per plant, number of ridges per fruit and number of seeds per fruit; Bhatt et al. (2015) for days to first flowering, days to first picking, plant height $(\mathrm{cm})$, number of nodes per plant, length of internode $(\mathrm{cm})$, number of primary branches per plant, stem girth $(\mathrm{cm})$, fruit length, fruit girth $(\mathrm{cm})$, fruit weight $(\mathrm{g})$, number of fruits per plant and Kumar and Reddy (2016) for plant height, intermodal length, fruit length, fruit weight, number of fruits per plant in okra.

Yield is the foremost and economically important character for any breeding programme. The results obtained from the present investigation revealed that fruit yield was high in crosses with lines exhibiting high $\times$ low and high $\times$ high GCA effects. Therefore, for the improvement of fruit yield in okra both additive and non-additive gene effects can be utilized which was further confirmed by the crosses exhibiting high- est per se performance also manifested high SCA effects. Thus, justifying the existence of high degree of dominance and additive gene action and results are in the agreement of findings of Vijay and Manohar (1986) and Dhankar et al. (1998), Sheela et al. (1998), Weerasekara (2006), Eswaran et al. (2007), Solankey and Singh (2010), Bhatt et al. (2015) and Kumar and Reddy (2016) for total yield per palnt.

\section{Conclusion}

The parental per se performance is a good indicator of its GCA effects, both general combining ability and per se performance of breeding lines should be considered together for assessing their breeding potentiality. GCA to SCA ratio was very low for the traits yield per plant indicating preponderance of non-additive gene action and hence these traits can be improved through recurrent selection for specific combining ability or heterosis breeding. Non-additive component of genetic variance was higher than additive component for number of fruits per plant, plant height, fruit length, days to first flowering, number of branches per plant and average fruit weight and can be improved through recurrent selection schemes. From this study it is concluded that parental lines KO-9 (0.05), KO-2 (0.04) and KO-4 (0.04) with higher GCA effects for yield and yield attributing characters could be exploited beneficially in future okra breeding programs by adopting appropriate breeding strategy. The crosses KO-11 $\times$ VRO-6 (0.10), KO-2 $\times$ Parbhani Kranti (0.9) and KO-14 $\times$ Arka Anamika (0.9) with significantly high SCA effects for yield could be exploited for the production of $F_{1}$ hybrids after further testing in multiple locations in the state. Therefore, it has a great scope for heterosis breeding to exploit the non-additive genetic variance observed for yield and yield components.

\section{REFERENCES}

Bhatt, J.P., Kathiria, K.B., Christian, S. S. and Acharya, R.R. (2015). Combining ability studies in okra (Abelmoschus esculentus (1.) moench) for yield and its component characters. Electronic J. of Plant Breeding, 6(2):479485

Dhankar, S.K., Dhankar, B.S. and Tewatia, A.S. (1998). A note on heterosis and combining ability in okra (Abelmoschus esculentus (L.) Moench). Haryana $J$. Hort. Sci., 27(3): 211-214

Eswaran, R., Thirugnanakumar, S., Sampathkumar, C.P., Anandan, A. and Padmanaban, C. (2007). Studies on the genetic causes of heterosis in okra [Abelmoschus esculentus (L.) Moench]. Plant Archives, 7(2): 721-724

Griffing, B. (1956). Concept of general combining ability in relation to diallel crossing system. Australian J. of Biological Sci., 9: 463-493

Kempthorne, O. (1957). An introduction to genetic statistics. John Wiley and Sons, New York, pp. 408-711

Kumar, P., Dixit, J. and Singh, B.P. (2006). Heterosis studies in okra. Haryana J. Hort. Sci., 35(1\&2): 120-123

Kumar, S. and Reddy, M.T. (2016). Combining Ability of 
Inbred Lines and Half-Diallel Crosses for Economic Traits in Okra (Abelmoschus esculentus (L.) Moench). Jordan J. of Agricultural Sci., 12(2):479-497

Manivannan, M.I., Rajangam, J. and Aruna, P. (2007). Heterosis for yield and yield governing traits in okra. The Asian J. Hort., 2(2): 96-103

Sheela, M.N., Manikantan, N.P. and Gopinathan, N.V., 1998, Heterosis in bhendi. Agric. Res. J. of Kerala, 26 (1): $23-28$

Singh, D.R. and Syamal, M.M. (2006). Heterosis in okra [Abelmoschus esculentus (L.) Moench]. Orissa J. Hort., 34(2): 124-127.

Singh, D.R., Singh, P.K., Syamal, M.M. and Gautam, S.S. (2009). Studies on combining ability in okra. Indian J. Hort., 66(2): 277-280.

Singh, B. and Goswami, A. (2015). Combining ability analysis in okra (Abelmoschus esculentus). Indian $J$. of Agricultural Sci., 85 (9): 1237-44

Solankey, S.S. and Singh, A.K. (2010). Studies on combin- ing ability in okra [Abelmoschus esculentus (L.) Moench]. The Asian J. Hort., 5(1): 49-53

Srivastava, M.K., Kumar, S. and Pal, A.K. (2008). Studies on combining ability in okra through diallel analysis. Indian J. Hort., 65(1): 48-51

Reddy, M. T., Haribabu, K., Ganesh, M. and Begum, H. (2011). Combining ability analysis for growth, earliness and yield attributes in okra (Abelmoschus esculentus (L.) Moench). Thai J. Agric. Sci., 44(3):207-218

Vijay, O.P. and Manohar, M.S. (1986). Combining ability in okra. Indian J. Hort., 43: 133-139

Wammanda, D.T., Kadams, A.M. and Jonah, P. M. (2010). Combining ability analysis and heterosis in a diallel cross of okra (Abelmoschus esculentus (L.) Moench). Afr. J. Hortic., 5(16):2108-2115

Weerasekara, D. (2006). Genetic analysis of yield and quality parameters in okra (Abelmoschus esculentus (L.) Moench.). M.Sc. Thesis, Univ. Agric. Sci., Dharwad. 